\title{
EFEKTIVITAS MODEL PEMBELAJARAN STAD DENGAN TGT DITINJAU DARI KEAKTIFAN BELAJAR MATEMATIKA KELAS IV SD
}

\author{
Roy Hermawan', Theresia Sri Rahayu², Wasitohadi ${ }^{3}$ \\ ${ }^{1}$ Pendidikan Guru Sekolah Dasar, Universitas Kristen Satya Wacana, royhermawan96@gmail.com \\ ${ }^{2}$ Pendidikan Guru Sekolah Dasar, Universitas Kristen Satya Wacana, th.rahayu@gmail.com \\ ${ }^{3}$ Pendidikan Guru Sekolah Dasar, Universitas Kristen Satya Wacana, wasitohadi@staff.uksw.edu
}

\begin{abstract}
INFO ARTIKEL
RiwayatArtikel:

Diterima: 23-03-2018

Disetujui: 06-04-2018

\section{Kata Kunci:}

STAD

ABSTRAK

Abstrak:Tujuan penelitian ini untuk mengetahui perbedaan efektivitas antara model pembelajaran STAD dengan model pembelajaran TGT ditinjau dari keaktifan belajar matematika siswa kelas $4 \mathrm{SD}$. Jenis penelitian ini adalah eksperimen semu (quasi experiment). Hasil Uji-T menunjukkan bahwa model pembelajaran TGT lebih efektif dibandingkan dengan model pembelajaran STAD. Hal ini dapat dibuktikan dari data yang diperoleh Uji-T menunjukkan $t$ hitung $>t$ tabel yaitu 2,216 $>2,021$, maka $\mathrm{H}_{\mathrm{o}}$ ditolak dan $\mathrm{H}_{\mathrm{a}}$ diterima. Dengan demikian keaktifan belajar matematika dalam penerapan model pembelajaran TGT lebih efektiv daripada model pembelajaran STAD.
\end{abstract}

TGT

Keaktifan Belajar

Matematika

\begin{abstract}
T The purpose of this study to determine the difference in effectiveness between STAD learning model with TGT learning model in terms of the activity of learning mathematic grade 4 elementary school. This type of research is a quasi experiment (quasi experiment). The T-Test results show that TGT learning model is more effective than STAD learning model. This can be proven from the data obtained $T$-test shows $t_{\text {arithmetic }}>t$ table is 2.216> 2.021, then Ho is rejected and Ha accepted. Thus the active learning of mathematic in the application of TGT learning model is more effective than STAD learning model.
\end{abstract}

\section{A. LATAR BELAKANG}

Matematika bukan hanya suatu ilmu yang akan dihadapi dalam pembelajaran di bangku sekolah saja, tetapi matematika menjadi dasar untuk dapat mengembangkan berbagai jenis teknologi. Daya pikir manusia juga dapat berkembang dan semakin maju karena peran matematika. Oleh karena itu, salah satu mata pelajaran utama dalam jenjang sekolah dasar adalah matematika. Menurut Yustinus (2017: 2-3) matematika adalah suatu struktur yang terorganisir dari pengetahuan yang mana setiap pendekatan atau langkahnya diasumsikan secara logis dari pendekatan dan langkah sebelumnya yang sudah dibuktikan. Sedangkan menurut Wahyudi \& Siswanti (2015: 26) matematika adalah ilmu yang mempelajari tentang bilangan dan geometri yang dapat disampaikan melalui simbol-simbol dimana memerlukan keterampilan berpikir resional dan bernalar dalam mengamati sebuah pola yang dapat dipecahkan dengan cara berpikir deduktif.

Dengan demikian dapat disimpulkan bahwa matematika adalah ilmu yang mempelajari tentang bilangan dan geometri yang dapat disampaikan melalui bahasa simbol, ilmu tentang pola yang teratur, struktur yang terorganisir yang mana setiap pendekatan atau langkah diasumsikan secara logis dengan pembuktian menggunakan cara berpikir deduktif. Pembelajaran matematika dimaksudkan untuk mengembangkan kemampuan siswa dalam memecahkan masalah dan mengkomunikasikan ide-ide atau gagasan dengan menggunakan simbol, diagram, tabel, dan media lainaya Menurut Yustinus (2017: 5) mata pelajaran matematika bertujuan agar siswa memiliki kemampuan sebagai berikut : (1) mamahami konsep dari matematika, menjelaskan keterkaitan antar konsep dan mengaplikasikan konsep tersebut secara akurat, luwes, tepat, dan efisien dalam menyelesaikan suatu permasalahan. (2) meggunakan penalaran terhadap pola dan sifat, melakukan menipulasi dalam membuat generalisasi, menyusun bukti, atau menjelaskan ide dan pernyataan matematika. (3) memecahkan masalah yang berkaitan dengan kemampuan mamahami masalah, merancang model, menyelesaikan model dan menafsirkan solusi yang diperoleh dari suatu masalah. (4) mengkomunikasikan ide-ide atau gagasan dengan simbol, diagram, tabel, dan media lainya untuk memperjelas suatu keadaan atau suatu masalah. (5) mempunyai sikap menghargai kegunaan matematika terhadap kehidupan, yaitu rasa ingin tahu, minat, dan perhatian dalam mempelajari matematika, serta sikap yang ulet dan selalu percaya diri dalam memecahkan suatu masalah. Dalam pembelajaran matematika khususnya materi bangun segi banyak, harus dapat 
melibatkan siswa secara aktif dalam mengontruksi konsep matematika itu sendiri.

Berdasarkan hasil wawancara terhadap guru kelas, kondisi pembelajaran matematika pada kelas IVA dan kelas IVB SD N Kalibeji o1 kurang sesuai dengan pembelajaran matematika, karena tidak melibatkan siswa secara aktif. Sehingga siswa kurang memahami materi dengan baik. Hasil Penilaian Tengah Semester (PTS) matematika, nilai rata-rata hasil tes kelas IVA dan IVB masih di bawah KKM yaitu sebesar 62,7 dan 65,4. KKM yang telah ditetapkan yaitu sebesar 70. Hal ini menjelaskan bahwa hasil belajar matematika kelas IVA dan kelas IVB masih rendah karena kurangnya keaktifan siswa dalam proses pembelajaran.

Salah satu model pembelajaran yang dapat menumbuhkan keaktifan belajar siswa adalah model pembelajaran Student Teams Achievement Division (STAD) dan Teams Games Tournament (TGT), kedua model pembelajaran tersebut termasuk dalam tipe pembelajaran kooperatif. Menurut Warsono \& Hariyanto (2014: 197) model pembelajaran STAD adalah model pembelajaran kooperatif yang bertujuan untuk mendorong siswa bekerjasama dan saling membantu antar anggota kelompok dalam memecahkan suatu permasalahan, tetapi pada akhirnya siswa bekerja secara mandiri dalam pembelajaran. Huda (2014: 201) mengemukakan bahwa model pembelajaran STAD merupakan tipe pembelajaran kooperatif dimana siswa dibagi menjadi empat sampai lima kelompok dengan level kemampuan akademik berbeda dan bekerjasama untuk mencapai tujuan pembelajaran yang telah ditetapkan. Tidak hanya dikelompokkan berdasarkan kemampuan akademik, siswa juga dikelompokkan secara beragam berdasarkan jenis kelamin, ras, dan etnis. Dengan demikian, dapat disimpulkan model pembelajaran STAD adalah model pembelajaran kooperatif yang dilakukan dengan cara siswa dibagi dalam kelompok yang beragam prestasi, jenis kelamin, dan suku dengan anggota kelompok sebanyak empat sampai lima orang untuk bekerjasama dalam menyelesaikan tugas kelompok, mengikuti kuis secara perseorangan, pemberian skor dan penghargaan prestasi tim untuk mencapai tujuan pembelajaran.

Menurut Hamdani (2011: 93-94) langkah-langkah STAD adalah sebagai berikut. (1) guru membentuk kelompok yang beranggotakan empat sampai lima orang dipilih secara heterogen, (2) guru menyajikan materi ajar, (3) guru memberikan tugas kepada setiap kelompok, (4) guru memberikan kartu-kartu pertanyaan (kuis) kepada siswa, (5) memberi evaluasi dari pembelajaran yang sudah dilakukan, dan (6) penutup. Kelebihan model pembelajaran STAD menurut Majid \& Rohman (2014: 226) yaitu setiap siswa dapat bekerjasama dan bertukar pikiran untuk menguasai materi pembelajaran.

Sedangakan model pembelajaran TGT menurut Hamdani (2011: 92) adalah salah satu model pembelajaran kooperatif yang mudah diterapkan, melibatkan siswa untuk saling bekerjasama (tutor sebaya), melibatkan keaktifan siswa dalam pembelajaran, dan mengandung unsur turnamen. Menurut Huda (2014: 197) dalam pembelajaran TGT, siswa ditempatkan dalam kelompok yang berbeda kemapuan (prestasi), komposisi tersebut dicatat dalam tabel turnamen. Dari pendapat dapat disimpulkan bahwa model pembelajaran TGT adalah salah satu model pembelajaran kooperatif yang cara pelaksanaanya siswa dibagi dalam kelompok yang beranggotakan lima sampai enam orang untuk bekerjasama dalam turnamen akademik dengan tujuan agar seluruh siswa aktif dalam proses pembelajaran.

Menurut Setyorini, dkk (2013: 60) langkah-langkah dan aktivitas pembelajaran TGT sebagai berikut. (1) pembelajaran diawali dengan tahap penyajian kelas dan siswa dikelompokkan dengan anggota kelompok sebanyak empat sampai lima orang, (2) kegiatan dalam turnamen yaitu persaingan pada meja turnamen dari empat sampai lima siswa dengan kemampuan yang sama atau setara, (3) apabila turnamen sudah berakhir, selanjutnya merekap/mencatat total skor yang telah kelompok dapatkan, dan (4) setelah merekap/mencatat skor, guru mengemukakan perolehan skor untuk setiap kelompok dan kelompok yang mendapat skor tertinggi diberikan penghargaan.

Kelebihan model pembelajaran TGT menurut Nugroho \& Rochman (2013: 162) yaitu dengan pengunaan waktu yang minimal siswa dapat menguasai materi pembelajaran secara maksimal dan proses pembelajaran menekankan pada keaktifan siswa.

Dengan diterapkanya model pembelajaran STAD dan TGT diharapkan dapat merangsang keaktifan siswa dalam proses pemebajaran. Keaktifan itu sendiri Menurut Anggraeni dan Wasitohadi $(2014 ; 126)$ adalah kesibukan siswa dalam kegiatan pembelajaran di sekolah dan di luar sekolah. Keaktifan siswa selama proses pembelajaran akan timbul interaksi antara guru dengan siswa maupun antar siswa. Menurut Rusman (2013: 86) Kegiatan atau aktivitas yang dilakukan pada saat proses pembelajaran disebut keaktifan belajar, dimana dalam melakukan keaktifan belajar dilakukan dengan menggunakan seluruh potensi yang bersifat fisik maupaun mental dari individu sehingga akan ada perubahan pada tingkah laku tertentu. Dari pendapat para ahli, maka dapat disimpulkan keaktifan belajar adalah aktivitas atau kesibukan siswa yang bersifat fisik maupun mental yang bertujuan untuk menimbulkan interaksi antara guru dengan siswa maupun antar siswa dimana kegiatan tersebut dilakukan secara sadar untuk mencapai perubahan tingkah laku tertentu.

Penelitian yang dilakukan Aka (2015) menyatakan bahwa model pembelajaran STAD (eksperimen 1) dan model pembelajaran TGT (eksperimen 2) tidak terdapat perberbedaan yang signifikan ditinjau dari hasil dan keaktifan belajar siswa. Skor rata-rata keaktifan belajar matematika kelas eksperimen 1 sebesar 82,44 dan skor rata-rata keaktifan belajar kelas eksperimen 2 sebesar 
80,91. Hasil uji beda rata-rata (Uji-T) skor keaktifan belajar menunjukka $t_{\text {hitung }}$ sebesar 0,280 dan $t_{\text {tabel }}$ sebesar 2,085. Hasil dari Uji-T nilai skor keaktifan belajar siswa menunjukkan $t_{\text {hitung }}$ lebih kecil dari $t_{\text {tabel }}$, maka dapat disimpulkan tidak terdapat perbedaan antara model pembelajaran STAD dengan model pembelajaran TGT ditinjau dari keaktifan belajar siswa.

Penelitian yang dilakukan Utami (2016) menyatakan bahwa model pembelajaran TGT (eksperimen 1) dan model pembelajaran STAD (eksperimen 2) berbeda secara signifikan ditinjau dari hasil belajar matematika kelas 3 SD. Hasil posttest kelas eksperimen 1 nilai rata-rata sebesar 76,53 dan nilai ratarata posttest kelas eksperimen 2 sebesar 71,35. Hasil UjiT menunjukkan bahwa nilai segnifikansi o,o10 dengan $t_{\text {hitung }}>t_{\text {tabel }}(2,648>1,993)$. Dengan demikian dapat disimpulkan bahwa terdapat perbedaan yang signifikan antara model pembelajaran TGT dengan model pembelajaran STAD ditinjau dari hasil belajar siswa.

Mengacu pada penelitian sebelumnya, maka akan dilakukan penelitian dengan rumusan masalah "Apakah Ada Perbedaan Keaktifan Belajar Matematika Siswa Kelas IV SD dalam Efektivitas Penggunaan Model Pembelajaran STAD dengan TGT ?”. Dan tujuan penelitian ini adalah "Untuk Mengetahui Apakah Ada Perbedaan Keaktifan Belajar Matematika Siswa Kelas IV SD dalam Efektivitas Penggunaan Model Pembelajaran STAD dengan TGT".

\section{B. METODE PENELITIAN}

Jenis penelitian ini adalah penelitian eksperimen dengan desain penelitian eksperimen semu (quasi experimental ). Desain penelitian eksperimen semu secara rinci disajikan melalui tabel 1 berikut ini.

TABEL 1.

DESAIN PENELITITIAN EKSPERIMEN SEMU

\begin{tabular}{|l|l|l|}
\hline $\mathbf{O}_{1}$ & $\mathbf{X}_{\mathbf{1}}$ & $\mathbf{O}_{\mathbf{2}}$ \\
\hline $\mathbf{O}_{\mathbf{3}}$ & $\mathbf{X}_{\mathbf{2}}$ & $\mathbf{O}_{\mathbf{4}}$ \\
\hline
\end{tabular}

Keterangan :

$\mathrm{O}_{1,3} \quad=$ Pengukuran pretest

$\mathrm{O}_{2,4}=$ Pengukuran posttest

$\mathrm{X}_{1} \quad=$ Perlakuan dengan model pembelajaran STAD pada kelas eksperimen 1

$\mathrm{X}_{2}=$ Perlakuan dengan model pembelajaran TGT pada kelas eksperimen 2

Penelitain ini dilakukan di SD N Kalibeji 01 semester 2 tahun pelajaran 2017/2018. Populasi yang digunakan dalam penelitian ini adalah seluruh siswa SD Negeri Kalibeji 01 sejumlah 236 siswa. teknik pengambilan sampel menggunakan teknik sampling Clausar Rondom Sampling yaitu teknik untuk menentukan sebuah sampel dari kelompok unit yang kecil. Sampel yang diambil adalah siswa kelas IVA sebagai kelas eksperimen 1 sejumlah 21 siswa dan siswa kelas IVB sebagai kelas eksperimen 2 sejumlah 21 siswa. Variabel bebas penelitian ini adalah model pembelajaran STAD dan model pembelajaran TGT, sedangkan variabel terikat adalah keaktifan belajar.

Teknik pengumpulan data menggunakan teknik observasi, wawancara, angket, dan tes. Observasi digunakan untuk mengamati perilaku guru dan siswa selama proses pembelajaran berlangsung, wawancara digunakan untuk mengetahui suatu permasalahan yang terdapat pada pembelajaran matematika SD N kalibeji 01, angket digunakan sebagai alat ukur keaktifan belajar siswa, dan tes digunakan sebagai alat ukur hasil belajar siswa. Teknik analisis data menggunakan uji prasyarat dilanjutkan dengan uji hipotesis. Terdapat dua uji prasyarat yaitu uji normalitas dan uji homogenitas. Setelah dilakukan uji prasyarat, selanjutnya dilakukan Uji-T (uji beda rata-rata) yang menjadi acuan untuk menguji hipotesis. Uji hipotesis dirumuskan dalam bentuk stasistik sebagai berikut.

$\mathrm{H}_{\mathrm{o}}: \mu 1=\mu 2$ (efektivitas model pembelajaran STAD dengan model pembelajaran TGT tidak berbeda secara signifikan ditinjau dari keaktifan belajar siswa)

$\mathrm{H}_{\mathrm{a}}: \mu 1 \neq \mu 2$ (efektivitas model pembelajaran STAD dengan model pembelajaran TGT berbeda secara signifikan ditinjau dari keaktifan belajar siswa).

\section{HASIL DAN PEMBAHASAN}

\section{Hasil}

Penelitian yang telah dilakukan di SD N Kalibeji 01 dengan menerapkan model pembelajaran STAD dan model pembelajaran TGT, diperoleh data yaitu adanya perbedaan skor rata-rata keaktifan belajar matematika kelas eksperimen 1 dan kelas eksperimen 2. Skor ratarata keaktifan belajar kelas eksperimen 1 sebesar 71,10 dan skor rata-rata keaktifan belajar kelas eksperimen 2 sebesar 78,24. Statistik deskriptif skor keaktifan belajar matematika kelas disajikan dalam tabel 2 sebagai berikut.

TABEL 2.

STATISTIK DESKRIPTIF SKOR KEAKTIFAN BELAJAR

\begin{tabular}{|c|c|c|c|c|c|}
\hline Kelas & N & Min & Max & Mean & Std. Dev \\
\hline Eks 1 & 21 & 54 & 92 & 71,10 & 11,207 \\
\hline Eks 2 & 21 & 57 & 93 & 78,24 & 9,628 \\
\hline
\end{tabular}

Skor keaktifan belajar dapat disajikan dalam deskripsi komparasi. Deskripsi komparasi berisi tentang perbandingan skor rata-rata keaktifan belajar kelas eksperimen 1 dan kelas eksperimen 2. Komparasi pengukuran skor keaktifan belajar disajikan dalam gambar 1 sebagai berikut. 


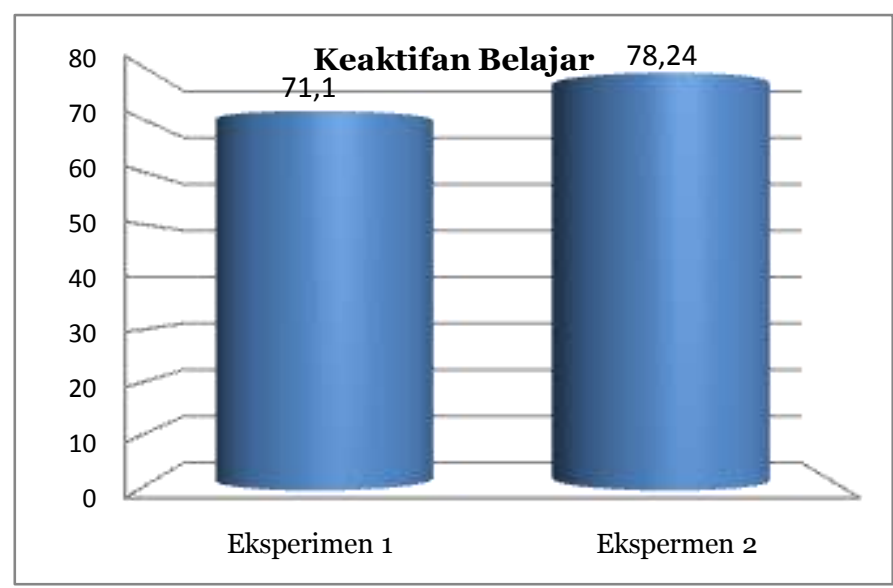

Gambar 1. Grafik Deskripsi Komparasi Pengukuran Keaktifan Belajar

Untuk mengetahui apakah setiap kelas berdistribusi normal dilakukan uji normalitas. Berdasarkan uji normalitas jika dilihat dari Saphiro-Wilk skor signifikansi keaktifan belajar siswa kelas eksperimen 1 sebesar 0,291 dan kelas eksperimen 2 sebesar 0,631. Karena nilai signifikansi tersebut $>0,05$ maka dapat disimpulkan bahwa persebaran data hasil skor keaktifan belajar matematika kedua kelas kelas berdistribusi normal. Selain itu, dilakukan uji homogenitas untuk mengetahui apakah kedua kelas memiliki varian yang sama atau homogen. Berdasarkan uji homogenitas dapat diketahui bahwa hasil output test of homogenity of variance skor keaktifan belajar matematika menunjukkan angka signifikansi pada based on mean sebesar 0,412, pada based on median sebesar 0,431, pada based on median and adjusted $d f$ sebesar 0,431, dan pada based on trimmed mean sebesar 0,415. Nilai signifikansi > 0,05 maka dapat dikatakan bahwa data skor keaktifan belajar matematika kedua kelas memiliki varian yang sama atau homogen.

Karena kedua kelas berdistribusi normal dan memiliki varian data homogen, maka dapat dilakukan Uji-T. Uji-T (uji beda rata-rata) dilakukan dengan Independent Samples Test sebagai acuan uji hipotesis. Hasil Uji-T skor keaktifan belajar kelas eksperimen 1 dan kelas eksperimen 2 disajikan dalam tabel 2 sebagai berikut.

TABEL 2.

HASIL UJI-T KEAKTIFAN BELAJAR

\begin{tabular}{|l|c|c|c|c|c|}
\hline & $\begin{array}{l}\text { Levene's Test } \\
\text { for Equality } \\
\text { of Variances }\end{array}$ & \multicolumn{4}{|c|}{$\begin{array}{c}\text { M-test for Equality of } \\
\text { Means }\end{array}$} \\
\cline { 2 - 6 } & $F$ & Sig. & $T$ & Df & $\begin{array}{c}\text { Sig. (2- } \\
\text { tailed) }\end{array}$ \\
\hline $\begin{array}{l}\text { Equal } \\
\text { variances } \\
\text { assumed }\end{array}$ &, 689 &, 412 & 2,216 & 40 & \\
\hline
\end{tabular}

Hasil uji beda rata-rata yang telah dilakukan ditinjau dari skor keaktifan belajar kelas eksperimen 1 dan kelas

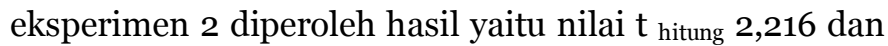

$\mathrm{t}$ tabel 2,021 dengan signifikansi 0,032. Karena signifikansi dari hasil Uji-T skor keaktifan belajar menunjukkan $<0,05$ dan $t$ hitung $>t$ tabel $(2,216>2,021)$, maka dapat disimpulkan Ha diterima yaitu efektivitas model pembelajaran STAD dengan model pembelajaran TGT berbeda secara signifikan ditinjau dari keaktifan belajar siswa.

\section{Pembahasan}

Berdasarkan hasil analisis data yang telah dilakukan, model pembelajaran yang digunakan yaitu model pembelajaran STAD dan model pembelajaran TGT diperoleh hasil yang berbeda. Dari pemberian kedua perlakuan di kelas yang berbeda tersebut, terdapat perbedaan yang signifikan dari skor kaektifan belajar siswa. Skor rata-rata keaktifan belajar siswa kelas eksperimen 1 (TGT) mempunyai skor rata-rata keaktifan belajar lebih tinggi daripada skor rata-rata keaktifan belajar siswa kelas eksperimen 2 (STAD) .

Jika dilihat dari kelebihan model pembelajaran TGT dalam pelaksanaan penelitian di lapangan pada kelas eksperimen 2, model pembelajran ini membuat siswa lebih aktif. Hal ini karena model pembelajaran TGT melibatkan siswa dalam semua langkah pembelajaranya. Pembelajaran TGT juga memuat turnamen akademik di dalam langkah-langkah pembelajaranya. Hal ini membuat siswa kelas eksperimen 2 sangat aktif dalam memecahkan masalah maupun mengerjakan tugas yang diberikan oleh guru. Siswa kelas eksperimen 2 sangat antusias pada saat guru menggunakan model pembelajaran TGT. Karena dengan adanya kompetisi antar kelompok, membuat kelompok ingin memenangkan sebuah turnamen akademik tersebut. Bukan hanya siswa yang aktif dalam proses pembelajaran, tetapi guru juga aktif membimbing dan mengarahkan siswa selama proses pembelajaran berlangsung. Sedangkan pembelajaran pada kelas eksperimen 1 dengan menggunakan model pembelajaran STAD, keaktifan belajaran matematika di kelas tersebut lebih rendah dari kelas eksperimen 2. Walaupun skor rata-rata keaktifan belajar siswa di kelas eksperimen 1 sudah tinggi yaitu mendapatkan skor rata-rata 71,10 , tetapi masih lebih rendah dari keals eksperimen 2 dengan skor rata-rata 78,24. Hal ini dikarenakan siswa lebih cenderung aktif dan antusias pada saat mengikuti turnamen akademik pada model pembelajaran TGT daripada mengikuti kuis pada model pembelajaran STAD.

Hasil penelitian sebelumnya menunjukkan hasil yang sama dilakukan oleh Kartika (2014) dengan judul "Efektivitas Penggunaan Model Pembelajaran Kooperatif Tipe TGT dalam Meningkatkan Hasil Belajar dan Aktivitas Siswa pada Pembelajaran Matematika Kelas IV SD Negeri Cukil o1 Semester II 2013/2014”, menyatakan bahwa efektivitas model pembelajaran TGT dan model pembelajaran konvensional berbeda secara signifikan ditinjau dari hasil dan keaktifan belajar siswa. Dengan 
demikian model pembelajaran TGT lebih efektiv dibandingkan dengan model pembelajaran konvesional. Diperkuat dengan penelitian yang dilakukan Darmayanti, dkk (2016) yang berjudul "Pengaruh Model TGT Ditinjau dari Hasil Belajar Matematika dengan Kovariabel Kemampuan Numerik pada Siswa Kelas V", menyatakan bahwa terdapat perbedaan model pembelajaran TGT dan model pembelajaran konvensional yang signifikan ditinjau dari hasil belajar siswa. Dari kedua penelitian di atas, dapat dilihat bahwa model pembelajaran TGT lebih efektiv dalam meningkatkan keaktifan dan hasil belajar matematika SD.

Namun, penelitian yang dilakukan juga berbeda dengan penelitian sebelumnya. Penelitian yang dilakukan Rahmawati dan Mahmudi (2014) yang berjudul "Keefektifan Pembelajaran Kooperatif STAD dan TAI Ditinjau dari Aktivitas dan Prestasi Belajar Matematika Siswa", menyatakan bahwa model pembelajaran STAD (eksperimen 1) dan model pembelajaran TAI (eksperimen 2) tidak berbeda secara signifikan ditinjau dari prestasi dan keaktifan belajar siswa. Tetapi keaktifan dan hasil belajar model pembelajaran STAD lebih baik daripada model pembelajaran TAI. Dari hasil penelitain tersebut dikatakan tidak sejalan karena, model pembelajaran STAD lebih efektiv ditinjau dari keaktifan dan hasil belajar matematika SD.

Model pembelajaran STAD dan TGT merupakan model pembelajaran kooperatif yang sama-sama berpusat pada siswa. Namun dalam penelitian ini, model pembelajaran TGT lebih efektiv dalam meningkatkan keaktifan belajar matematika siswa kelas 4 SD N Kalibeji o1 daripada model pembelajaran STAD.

\section{SIMPULAN DAN SARAN}

Berdasarkan hasil penelitian yang telah dilakukan pada kelas eksperimen 1 dengan menggunakan model pembelajaran STAD dan kelas eksperimen 2 menggunkan model pembelajaran TGT, dapat disimpulkan bahwa terdapat perbedaan efektivitas modal pembelajaran STAD dan model pembelajaran TGT yang signifikan ditinjau dari keaktifan belajar siswa kelas 4 SD N kalibeji 01 pada mata pelajaran matematika khususnya materi bangun segi banyak. Hal ini dapat dilihat dari $t_{\text {hitung }}$ sebesar 2,216 dan $t$ tabel sebesar 2,021 dengan signifikansi 0,032. Karena signifikansi dari hasil Uji-T skor keaktifan belajar menunjukkan < 0,05 dan t hitung $>t$ tabel $(2,216>2,021)$ dapat diartikan bahwa kedua model berbeda secara signifikan. Hal ini diperkuat dengan perbedaan skor rata-rata keaktifan belajar matematika pada kelas eksperimen $1(71,10)$ lebih rendah dari kelas eksperimen $2(78,24)$.

Dari hasil penelitian yang telah dilaksanakan, saran yang dapat diberikan guna meningkatkan kualitas pembelajaran adalah sebagai berikut. (1) guru dapat menumbuhkan keaktifan belajar matematika siswa dengan menerapkan model pembelajaran TGT lebih sering dalam pembelajaran. Guru juga bisa menumbuhkan keaktifan belajar matematika dengan menggunakan model pembelajaran STAD karena model pembelajaran ini juga berpusat pada siswa dan terbukti memperoleh skor keaktifan belajar yang cukup tinggi. (2) Sekolah dapat menggunakan model pembelajaran TGT dan STAD untuk diterapkan di semua tingkatan kelas, sehingga dapat meningkatkan mutu pendidikan yang lebih baik dan menghasilkan lulusan yang terampil dan handal.

\section{UCAPAN TERIMA KASIH}

Ucapan terima kasih yang sebesar-besarnya diberika kepada dosen pembimbing senantiasa memberikan bimbingan, nasehat, dan motivasi dengan penuh kesabaran sehingga penelitian ini dapat selesai dengan baik. Ucapan terima kasih juga diberikan kepada kepala sekolah SD N Kalibeji o1 yang telah mengijinkan melakukan penelitian di SD tersebut. Tidak lupa terimakasih kepada orang tua dan teman-teman yang telah mendukung dan menemani selama proses penelitian.

\section{DAFTAR RUJUKAN}

[1] Aka, Kukuh Andri. 2015. Komparasi Penerapan Model STAD dan TGT Terhadap Hasil Belajar dan Aktivitas Siswa (Studi pada Siswa Kelas V Mata Pelajaran PKn di SDN Bendo, Kec. Pare, Kab. Kediri). Jurnal Profesi Pendidikan Dasar, 2 (2), 103-111.

[2] Anggraeni, Vian \& Wasitohadi. 2014. Upaya Peningkatan Keaktifan dan Hasil Belajar Matematika Siswa Kelas 5 Melalui Model Pembelajaran Kooperatif Tipe Teams Games Tournament (TGT) di Sekolah Dasar Virgo Maria 1 Ambarawa Semester II Tahun Pelajaran 2013/2014. Jurnal Satya Widya, 30 (2), 121-136.

[3] Darmayanti, K.A, Dkk. Pengaruh Model TGT Terhadap Hasil Belajar Matematika dengan Kovariabel Kemampuan Numerik pada Siswa Kelas V. E-jurnal PGSD Universitas Pendidikan Ganesha, 4 (1), 1-10.

[4] Hamdani. 2011. Strategi Belajar Mengajar. Bandung: Pustaka Setia.

[5] Huda, Miftahul. 2014. Model-Model Pengajaran \& Pembelajaran: Isu-Isu Metodis dan Paradikmatis. Malang: Pustaka Pelajar.

[6] Kartika, Yunita Tri. 2014. Efektivitas Penggunaan Model Pembelajaran Kooperatif tipe TGT dalam Meningkatkan Hasil Belajar dan Keaktifan Siswa pada Pembelajaran Matematika Kelas IV SD Negeri Cukil o1 Semester II 2013/2014. Skripsi. Universitas Kristen Satya Wacana. Salatiga.

[7] Nugroho, Dian Riski \& Rachman, Abdul. 2013. Penerapan Model Pembelajaran Kooperatif Tipe (Teams Games Tournament) TGT terhadap Motivasi Siswa Mengikuti Pembelajaran Bola Voli Di Kelas X SMAN 1 Panggul Kabupaten Trenggalek. Jurnal pendidikan olahraga dan kesehatan, 1 (1) , 161-165.

[8] Rahmawati, Rina Dyah, dan Mahmudi, Ali. 2014. Keefektifan Pembelajaran Kooperatif STAD dan TAI Ditinjau dari Aktivitas dan Prestasi Belajar Matematika Siswa. Jurnal Prima Edukasia, , 2 (1), 102-115. 
[9] Rusman, 2013. Model-Model Pembelajaran: Mengembangkan Profesionalisme Guru. Jakarta: PT Rajagrafindo Persada.

[10] Sanjaya, Wina. 2013. Penelitian Pendidikan: Jenis, Metode, dan Prosedur. Bandung: Kencana Prenada Media Group.

[11] Setyorini, dkk. 2013. Pengaruh Pembelajaran Kooperatif Tipe Teams- Games- Tournament (TGT) dan Metode Ekspositori terhadap Hasil Belajar PKn Siswa Kelas XI MAN Temanggung Semester Ganjil Tahun Pelajaran 2012/2013. Jurnal Satya Widya, 29 (1), 58-64.

[12] Utami, Dessyi Dwi. 2016. Perbedaan Hasil Belajar Matematika Kelas 3 SD Gugus Jaka Tingkir Menggunakan Model Pembelajaran Kooperatif Tipe Teams Games Tournament dan Stident Teams Achievement Division. Skripsi. Universitas Kristen Satya Wacana. Salatiga.

[13] Wahyudi \& Siswanti, Mia Christy. 2015. Pengaruh Pendekatan Saintifik Melalui Model Discovery Learning dengan Permainan terhadap Hasil Belajar Matematika Siswa Kelas 5 SD. Jurnal Scholaria, 5 (3), 23-36.

[14] Warsono \& Hariyanto. 2014. Pembelajaran Aktif: Teori dan Asesmen. Surabaya: PT Remaja Rosdakarya.

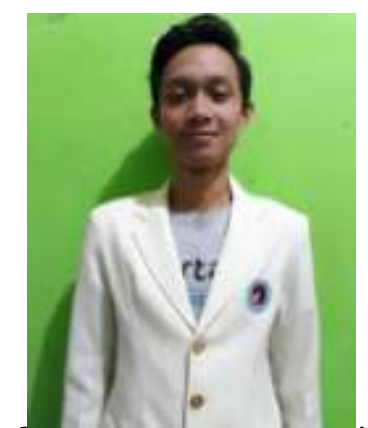

\section{PROFIL PENULIS UTAMA}

Penulis bernama lengakap Roy Hermawan lahir pada tanggal 15 Mei 1996 di Kabupaten Boyolali. Lahir dari sepasang suami istri yang bernama Sumadi dan Sartini mempunyai 2 saudara laki-laki. Penulis telah mengenyam pendidikan selama 16 tahun. Pendidikan sekolah dasar dilalui di SD Negeri Kaligentong 02 Ampel, Boyolali pada tahun 2002 - 2008. Pendidikan sekolah menengah pertama di SMP Negeri 2 Ampel, Boyolali pada tahun 2008 - 2011. Pendidikan sekolah menengah atas dilalui di SMK Negeri 1 Tengaran, Semarang pada tahun 2011 - 2014. Pada saat ini penulis melanjutkan studi di Universitas Kristen Satya Wacana sejak tahun 2014, semoga diberi kelancaran agar dapat mengikuti wisuda pada Juli 2018 mendatang. Kritik dan saran yang membangun sangat penulis nantikan berkaitan dengan pengembangan dari hasil penelitian ini bisa dikirim ke email penulis di royhermawan96@gmail.com. 